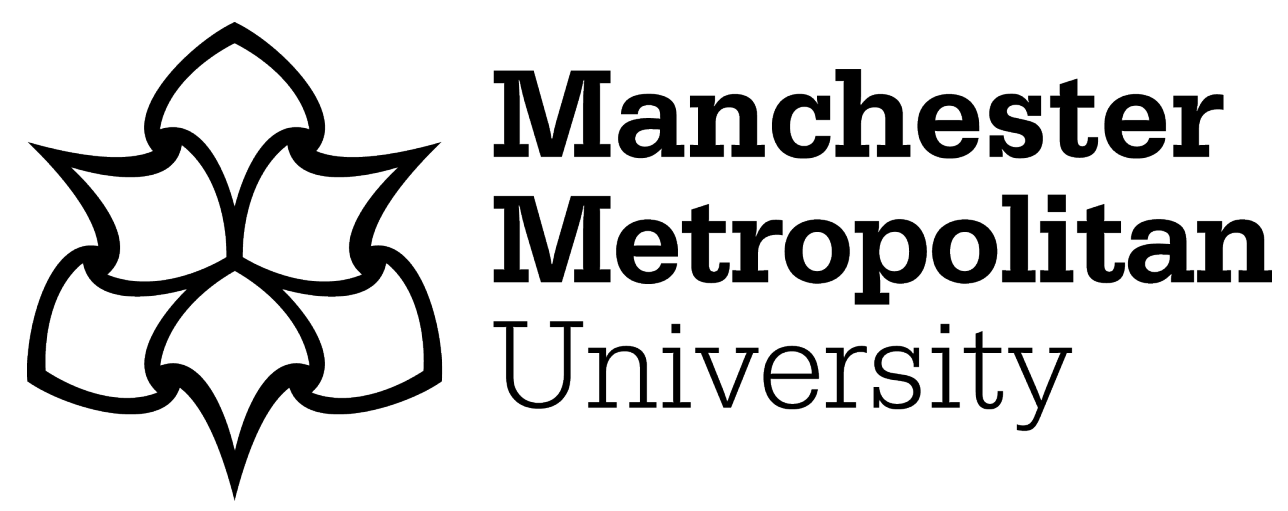

Berry, C and Hay, C (2014) The Great British 'rebalancing' act: the construction and implementation of an economic imperative for exceptional times. British Journal of Politics and International Relations, 18 (1). pp. 3-25. ISSN 1467-856X

Downloaded from: https://e-space.mmu.ac.uk/620777/

Publisher: SAGE Publications

DOI: https://doi.org/10.1111/1467-856X.12063

Please cite the published version 
This is the peer reviewed version of the following article: 'The Great British "rebalancing" act: the construction and implementation of an economic imperative for exceptional times", which has been published in final form at http://onlinelibrary.wiley.com/doi/10.1111/1467856X.12063/abstract. This article may be used for non-commercial purposes in accordance with Wiley Terms and Conditions for Self-Archiving.

\title{
The Great British 'rebalancing' act: the construction and implementation of an economic imperative for exceptional times
}

\author{
Craig Berry and Colin Hay
}

\begin{abstract}
The 'rebalancing' of the British economy has become perhaps the central motif in the public political economy of adjustment to the financial crisis. The paper examines the social construction of the 'rebalancing' imperative and associated policies, arguing that rebalancing discourse has served to circumscribe the parameters of acceptable state intervention in response to the crisis. It is, accordingly, to be seen as a temporary exception, after which laissezfaire can be restored. But is there any evidence for such a rebalancing? In the second half of the paper we assess the extent to which its objectives have been realised in substantive economic policy change, demonstrating a disjuncture between the rhetoric and practice of rebalancing - a communicative dissonance. This leads us to question not only the extent to which rebalancing has been pursued in public policy, but also the likelihood that the interventions delineated by rebalancing can herald genuine economic change.
\end{abstract}

Keywords: British economy, economic policy, crisis, rebalancing, economic imperatives, coalition government

\section{Introduction}

Though it has its origins in the early 2000s (Froud et al, 2011), the idea that the British economy is unbalanced has emerged as perhaps the single defining motif of official economic policy discourse in Britain since the global financial crisis. Its analogue, the rebalancing imperative, as we shall term it, has, over this time, become the core 
principle justifying economic intervention by the state in exceptional times. The concept of rebalancing has been employed by elite policy-makers to refer to a long but relatively coherent list of economic issues, most obviously the contribution of different sectors and different regions to the British economy, but also international trade, and the relative importance of saving and investment in contrast to, respectively, private debt and consumption. Overall, we contend, rebalancing discourse serves in effect to provide a new, if temporally delimited, moral political economy of state intervention: for as long as a strong case for sectoral (or other) rebalancing can be maintained, state intervention to redress that balance is justified. Such state intervention is good, yet by the same token, other forms of state intervention (which cannot be justified in terms of the rebalancing imperative), or the very same state intervention extended beyond the (exceptional) period in which the economy can be shown to be unbalanced, are bad. As such, we contend, rebalancing serves to circumscribe, in public discourse, the parameters of state intervention - both sectorally/regionally, in that such state intervention should be limited to initiatives that will serve to restore a (natural) condition of economic balance and temporally, in that the imperative (and the legitimation for intervention it provides) only apply during exceptional times (in which the imbalance persists).

In the context of British economic policy making since the 1980s, this rebalancing discourse is an intriguing and interesting innovation which bears close scrutiny. It is intuitively interesting, we suggest, for four principal reasons: firstly, like many other ostensibly persuasive British economic policy logics in recent years, it is couched as an imperative - a non-negotiable and binding constraint if good economic performance is to be restored. Secondly, however, unlike many such non-negotiable economic imperatives (such as competitiveness, fiscal rectitude or central bank independence), it is constituted as an internal rather than an external imperative (on the appeal to external economic imperatives as non-negotiable see, for instance Hay 2004; Hay and Rosamond 2002; Hay and Smith 2005; Watson and Hay 2004). Thirdly, it is simultaneously both repoliticising and depoliticising: It is repoliticising in the sense that it countenances state intervention where otherwise it would not typically be seen as legitimate and, more specifically, a particular form of state intervention capable of readjusting the boundaries of economic activity. Yet it is also depoliticising in that it 
presents rebalancing as a logic of no alternative, and as a technical fix to what is presented as a self-evidently technical economic problem.

Finally, and as we have already alluded to, rebalancing constitutes a heavily circumscribed and conditional imperative - a license to intervene that is strictly timedelimited and specific to certain limited outcomes. It defines an imperative which seeks to restore a normal condition of balance to the economy, in the exceptional circumstances of imbalance. It posits, in effect, a condition of dynamic stability which the crisis has disrupted (by the conduct of others), and which can only be restored by a degree of state intervention which would not normally be warranted. Yet what is perhaps most intriguing about the rebalancing imperative is that it is difficult (and increasingly difficult) to reconcile with economic policy content. It is difficult to discern the rebalancing that features so prominently, alongside austerity, in the public rationale offered for economic policy change. The same, it need hardly be pointed out, certainly cannot be said of austerity itself.

Interestingly, the diagnosis of the British economy as structurally unbalanced bears some ostensible similarity with the analysis associated with the identification and critique of a 'privatised Keynesian' or 'Anglo-liberal growth model' (ALGM) (see Crouch 2009; 2011; Hay 2013; Watson 2010). Rebalancing and ALGM analysis both draw attention to the component parts of economic growth, rather than judging the health of the economy simply on the basis of aggregate performance as gauged in output growth. (The key distinction of ALGM analysis in this regard is probably the emphasis placed on the housing market as a source of funds for private consumption, and the apparent decline or stagnation in earnings for many employees in the pre-crisis period, neither of which have featured in the coalition's rhetoric on rebalancing.) Furthermore, both portray policy-makers as having acted to exacerbate the economy's flaws (or imbalances) in recent years (whether for short-term gain, or through ignorance or negligence, or both). While the specific concept of economic balance has not featured predominantly in ALGM analysis (other than in use of the now standard terms of debate about international trade, for instance), the similarities suggest that rebalancing discourse, in offering a diagnosis for Britain's economic ills, has at least some analytical merit, and cannot be dismissed as merely a rhetorical device. Even if rebalancing were 
primarily rhetorical rather than substantive, it would remain appropriate for political economists to subject to scrutiny the rationale for policy action being offered by political leaders, and any progress towards such an anticipated or desired results in terms of economic outcomes. When the case for rebalancing can be made on its own terms, we have even more reason to seek to scrutinise the degree to which the perceived imperative has been acted upon, quite apart from the simple desire to hold politicians to account. This is not to suggest, however, that inquiry into the 'meaning' or discursive implications of rebalancing is not also required, and that such implications do not impinge heavily upon what is knowable about economic balance, and what is achievable through rebalancing. In what follows, we seek to combine an assessment of both.

As such, this article subjects rebalancing, or more precisely progress towards a condition of greater economic balance (within the terms of the discourse), to empirical analysis. It does so by offering a comprehensive assessment of the latest available evidence from official sources - a form of immanent critique, in effect (Adorno 1973; Antonio 1981). It argues, primarily, that there remains and is likely to remain a considerable gulf between the rhetoric of rebalancing, on the one hand, and still largely illusory objective of the sectoral recomposition of the economy, on the other. Striving for balance, rhetorically, has not as yet led to any profound economic change. Moreover, through both its ambiguity and the temporal and sectoral circumscription of the forms of intervention countenanced, the rebalancing imperative may in fact serve to sustain a pre-crisis economic order; evidence of a failure to rebalance is unlikely to dampen enthusiasm for the agenda itself. The first section of the article briefly documents rebalancing discourse, commenting also on some of the apparent implications of its employment for how the British economy, and the state's role within it, is conceived. The second section offers an overview of how coalition economic policy relates to rebalancing, and the third section, after discussing various analytical issues, presents the empirical analysis.

\section{Rebalancing as discourse}


This section offers an overview of the main appeal to the rebalancing motif by British politicians in recent years. It focuses on the coalition government's communicative discourse around its economic policy priorities, that is, its attempt to create a framing rationale, in publicly accessible language, for capturing economic policy objectives across a range of fields (on the distinction between communicative and coordinative discourses see, especially, Schmidt 2008; Hay and Rosamond 2002).

Rebalancing had become a central and defining feature of the Conservatives' public discourse in advance of the 2010 election. The party's election manifesto promised 'a more balanced economy' (Conservative Party, 2010). A preceding speech by future Chancellor of the Exchequer George Osborne (2010) claimed academic support for rebalancing, arguing that ' $\mathrm{t}]$ he economics profession is in broad agreement that the recovery will only be sustainable if it is accompanied by an internal and external rebalancing of our economy'. The Liberal Democrats' manifesto also contained several references to economic balance. It was perhaps unremarkable, therefore, that the coalition agreement between the two parties should state very clearly:

We want to create a fairer and more balanced economy, where we are not so dependent on a narrow range of economic sectors, and where new businesses and economic opportunities are more evenly shared between regions and industries (HM Government, 2010: 9).

This was quickly followed by a speech by the new Prime Minister, David Cameron (2010), which argued that 'our economy has become more and more unbalanced, with our fortunes hitched to a few industries in one corner of the country, while we let other sectors like manufacturing slide'. In 2011, the coalition produced its 'plan for growth', therefore demonstrating how the rebalancing motif had been implanted into the departmental machinery of Whitehall:

Sustainable growth requires a rebalancing of the UK economy away from a reliance on a narrow range of sectors and regions, to one built on investment and exports, with strong growth more fairly shared across the UK (HM Treasury and Department for Business, Innovation and Skills, 2011: 28). 
Several rebalancing priorities emerge from the plan for growth and the surrounding discourse: reducing private debt, increasing private savings, increasing business investment, improving the trade balance, boosting sectors other than finance (particularly manufacturing), and boosting regions other than London and the South East. Each might be seen to provide the basis for an evaluation of the Coalition's rebalancing proposition on its own terms (a task to which we turn directly in the next section).

The generally implicit, though sometimes explicit, accusation is that the outgoing Labour government had caused or failed to address the economic problems which now give rise to this agenda. Clearly, the notion of rebalancing suggests that there once was balance, that is, some natural economic balance that it is possible to attain. Expressed in this context, economic balance implicitly exalts the economic order that was evident before New Labour's reckless economic stewardship. In this respect, what is important about the discourse of balance, imbalance and rebalancing is that it clearly apportions blame for the crisis and the costs of adjustment to its legacy. Imbalance is an unnatural aberration, the product of poor economic management by others, and rebalancing is a difficult and exceptional challenge which perhaps cannot be expected to yield clear (growth) dividends immediately. That is a comforting and arguably convenient conclusion.

However, rebalancing discourse was employed by Labour in government before 2010, most notably in the Pre-Budget Report (now known as the Autumn Statement) published in 2009. The document contains several references to rebalancing, although usually in relation to specific issues (mainly business investment and exports), rather than in terms of an overall agenda, and usually in relation to an expectation that such rebalancing would occur naturally, post-crisis, rather than as an agenda actively being pursued. It was not, in short, an imperative. Although not using the specific term, in his speech accompanying the Pre-Budget Report, then Chancellor of the Exchequer Alistair Darling stated: 
[G]rowth will come from more varied sources and not depend as much on the financial sector which will, of course, remain an important part of our economy. Growth will be driven by fresh opportunities to export as the global economy expands and by investment by business in the key industries of the future (Darling, 2009b).

This passage is particularly interesting as it implies a quite stark contrast between economic performance at the time and that anticipated in the future (which will be more varied in its sources, less dependent on the financial sector, and so forth) but without any clear sense of the agency required to effect the transition. A natural process of adjustment and healing would appear to be envisaged without the need for any concerted state intervention. These remarks echoed similar remarks in Darling's Budget speech earlier that year.

In a similar vein, if perhaps with a little more rhetorical flair, Peter Mandelson, early in 2010, as Secretary of State for Business, Innovations and Skills stated:

And let me say this quite bluntly: for the past decade, we have allowed ourselves to become over-dependent on the City and financial services for growth and our tax revenues. That is why, without wishing the financial sector to be smaller, we need other industrial strengths and sources of revenue to grow faster (Mandelson, 2010).

The Labour government were of course reluctant to apportion blame to themselves for causing such imbalances. Although Gordon Brown does not appear to have personally employed rebalancing discourse to any significant extent in a domestic context, his view that the inadequacy of international financial regulation had created global economic imbalances, and ultimately the financial crisis, indicates Labour's view on the political source of economic disruption (see Brown, 2010). However, it would be inaccurate to identify the Labour government under Gordon Brown's leadership as the source of the rebalancing motif in elite-level public discourse. Indeed, before the establishment of the coalition government, the public figure probably most responsible for promulgating rebalancing discourse was then Governor of the Bank of England, Mervyn King. He told 
the Treasury select committee in 2008 that rebalancing - defined mainly in terms of reducing household consumption in favour of business investment - was 'something that I have been expecting, and, indeed, perhaps hoping for, for some time' (cited in House of Commons Treasury Committee, 2008). This might seem at first like a comment prompted by the benefit of hindsight. But, tellingly, he was in fact merely restating a theme he had set out in almost identical terms as early as 2002:

The strength of consumption and the weakness of net exports have led to an imbalance between manufacturing and services. Manufacturing profitability has fallen by more than half over the past five years, while in less easily traded services profitability has been broadly unchanged. The need to rebalance the British economy is clear (King, 2002).

A basic search using the terms 'rebalancing' or 'unbalanced' on the websites of major news organisations in Britain shows that rebalancing discourse appears to have entered the lexicon of mainstream media commentary on the economy around this time, or soon afterwards, with a Financial Times editorial in 2005 in fact criticising King for his part in the failure to address evident imbalances in the British economy. The fact that elite discourse on the economy after the financial crisis - which, of course, very few orthodox voices saw coming (Hindmoor and McConnell, 2013) - resembles the communicative discourse being promulgated by at least some parts of the British political elite before the crisis, albeit in a more pronounced way, is perhaps suggestive of the conservatism of rebalancing discourse.

There certainly appears to have been a period, however, when rebalancing discourse went quiet among policy-makers. It has not been employed by Ed Miliband since he became Leader of the Labour Party in 2010 to any significant degree, with no reference to rebalancing or related terms in his first four party conference speeches. Interestingly, an April 2014 speech by Miliband on Labour's plans for regional devolution made no reference to balance or imbalance, nor to rebalancing - though it was still reported by The Guardian as an agenda to 'rebalance growth' (Wintour, 2014). After featuring in George Osborne's Budget speech in 2012, it did not feature in his 2013 Budget speech, or the two Autumn Statement speeches delivered during this period. It may be possible 
to relate this relative silence from the Conservatives to the improving performance of the British economy; after strong GDP growth in the third quarter of 2012, associated with the London Olympics, consistently positive growth results returned in 2013. The fact that growth has returned without (as will be discussed below) any significant signs of achieving the stated rebalancing priorities may also be relevant. However, not everybody in government was reticent about the British economy's balance during this period. Liberal Democrat Business Secretary Vince Cable argued (in an almost Cassandra-like way given the improvement in growth performance) that the economy

needs rebalancing through a shift to exports and investment rather than debtbased consumption - specifically towards long-term investment in productive assets rather than short-term speculative property accumulation. To succeed in this task is necessarily the work of many years (Cable, 2013).

However, in February 2014, after a long silence on the theme, George Osborne also returned to the rebalancing motif. This was, in part, to proclaim the success of rebalancing, arguing for instance that manufacturing and construction were contributing to strong growth results. Yet he added, perhaps tellingly:

[T] he recovery is not yet secure and our economy is still too unbalanced. We cannot rely on consumers alone for our economic growth, as we did in previous decades. And we cannot put all our chips on the success of the City of London, as my predecessors did. Britain is not investing enough. Britain is not exporting enough. There are encouraging signs. Both business investment and exports are forecast to grow. But we can't be passive observers of the forecasts. We need to roll up our sleeves, get to work and make it happen (Osborne, 2014b).

In his Budget speech a month later, Osborne explained that '[a] resilient economy is a more balanced economy with more exports, more building, more investment - and more manufacturing too. We've got to support our manufacturers if we want to see more growth in our regions' (Osborne, 2014a). It is of course difficult to identify whether these later examples of the Conservatives' rebalancing discourse differ from those evident in the 2010-2012 period. Certainly, there is no explicit criticism here of 
private debt (in contrast to Cable's argument) though there would at least appear to be an acknowledgement of the increasing importance of private debt to growth - a theme we explore in more detail presently. Moreover, and in contrast to earlier quotes and references, rebalancing is here presented not only as an imperative (as something which needs to be done), but as an animating imperative and vision (informing directly what might be done and is being done).

It is worth noting that in his February 2014 speech, Osborne described the City of London as a 'success' - the sole caveat being that we have become too dependent on this success, not that such success may itself have deleterious consequences. This indicates another important hallmark of rebalancing discourse, that is, the suggestion that all of the component parts of the economic model are legitimate, and capable of functioning effectively, but they have simply become disordered or distended for some reason (for an alternative analysis, see Hay and Payne 2015). There is a sense, for instance, that sectors such as manufacturing can be boosted simply by policy-makers deciding to focus their fiscal levers on the sector, and not by focusing on the relationship between manufacturing and sectors such as finance. Different sectors and regions are presented as equally capable of strong growth, irrespective of the existing interplay and interaction between sectors and regions and the power relations inherent in such dynamics. State intervention is limited both temporally and inter-sectorally to encouraging, levering or cajoling sectors closer or further away from the economy's fulcrum so that a natural - and self-sustaining - balance can be re-secured. Closely related to this is the notion that achieving balance would require only minor, technocratic modifications to economic practice, rather than radical change (see Froud et al, 2011). For this reason, the primary fiscal levers pulled by the state are minor tax adjustments, rather than, say, major public investment programmes or corporate governance reform. In this sense, rebalancing echoes the motif of 'stability', pivotal to New Labour's economic statecraft (Clift and Tomlinson, 2006). As such, rebalancing implies a further imperative, albeit for inaction rather than action. In terms of more stringent financial regulation, not throwing the baby out with the bathwater is established as a policy priority, achievable only via sober, technocratic decision-making processes rather than a politicised or emotive response to the financial crisis. 
Before discussing the rebalancing agenda in practice (what has been done), it is important to discuss here the relationship between rebalancing and elite discourse on 'austerity', or in other words, the extent to which the coalition government's desire to reduce the public deficit has been presented as an issue of economic balance. This is not a straightforward issue. Clearly, the idea that the public finances themselves are unbalanced (between revenue and spending) is commonplace in British politics. Yet in terms of the balance between the public and private sectors, of the sources cited above, only the Conservative Party's 2010 election manifesto strongly identifies high levels of public spending as a key source of economic imbalance. Interestingly, however, as explored in the next section, a retreat by the state or public sector is often presented implicitly as a pre-requisite of achieving balance in the private sector. As this suggests, whether seen as complementary or in tension, both themes have played an important discursive role, meaning that rebalancing within the private sector can be usefully explored while avoiding the implication that this is all the coalition government cares about.

\section{Rebalancing as programmatic intent}

This section briefly discusses the coalition government's policy programme, insofar as it relates to rebalancing. Of course, the main agenda pursued by the government has been cuts in public spending. While not unrelated to rebalancing, this agenda has been presented principally using communicative discourse related to the concept of austerity. Pursuing rebalancing, in contrast, does not automatically necessitate such cuts; indeed, the coalition has frequently sought to highlight areas where new public investment initiatives (despite a significant reduction in general spending) ostensibly boost the rebalancing effort, such as the HS2 rail network.

Yet the notion that the state must get out of the way of the private sector, in order for rebalancing to occur, has animated rebalancing policies to some extent. Deregulatory initiatives such the Red Tape Challenge and so-called 'bonfire of the quangos' were heavily promoted early in the life of the coalition, but have led to relatively few substantive reforms. More important have been changes to taxation, as the government has sought to introduce tax 'incentives' (and simplification) to encourage private sector 
economic actors to grow, invest, and create jobs; the main example being the gradual reduction of the main rate of corporation tax to 20 per cent by 2015 (the same rate applied to small firms). There have also been cuts to personal taxes, with a reduction in the top rate of income tax to 45 per cent from 50 per cent, and gradual increases in the income tax personal allowance. These tax cuts of course reduce Exchequer revenue, and are therefore, ostensibly, anti-austerity. Interestingly, the personal tax cuts are also proconsumption. There have, however, been changes which have restricted consumption, such as a higher rate of Value Added Tax, and cuts to social security benefits (although the latter should probably be seen in the context of a broader attempt to incentivise employment; the flagship welfare reform, Universal Credit, costs more than the systems it is replacing, other things being equal (Brewer et al, 2011)).

The coalition government has proselytised consistently the need to boost manufacturing; its early agenda in this regard was laid out in the 2011 'plan for growth', which identified 'advanced manufacturing' as a priority. However, with the partial exception of increased support for university research centres focused on manufacturing, policy has replicated longstanding practices within British industrial policy: interventions are aimed at the micro level, and generally take the form of 'soft' support, such as advice services, gateway services and the dissemination of best practice (Buigues and Sekkat, 2009). More recently, attempts have been made to reduce manufacturers' energy costs by removing environmental levies, although this probably represents a partial marginalisation of the advanced manufacturing agenda, and should be seen in light of related efforts to support 'reshoring', that is, the return of low-skilled manufacturing production to Britain that had previously been 'offshored', facilitated principally by declining relative wages in the British manufacturing sector. Manufacturers have also, apparently, been the main target of increases to the annual investment allowance, that is, the capital investment that firms are able to offset against their corporation tax liabilities - the allowance has been increased gradually to $£ 0.5$ million, with this rate persisting to 2015. However, reform of the allowance will have a limited impact on the manufacturing sector, as it relies on investment being funded by retained profits. British manufacturing has become increasingly unprofitable, and in any case, is largely typified by small firms. 
In terms of other initiatives in support of investment, the government's flagship National Infrastructure Plan offers a long list of investment ambitions, albeit with the vast majority of funding expected to come from private sources (see Helm, 2013). The government has also looked to pension funds to invest greater amounts in infrastructure, but the Pension Infrastructure Platform has failed to attract significant support, with most contributions coming from public sector or pseudo-public pension funds. ${ }^{1}$ The Bank of England's Funding for Lending scheme was intended to encourage banks to make finance available to the corporate sector, particularly small firms, but it has been used principally to support mortgage lending (its terms were therefore revised by the Bank in November 2013). By abolishing the Regional Development Agencies (replaced in name only by Local Enterprise Partnerships), the government has forgone the approach to regional investment which has traditionally served as a proxy for industrial policy in Britain (Buigues and Sekkat, 2009).

Attempts to boost manufacturing have not encompassed efforts to tackle the sector's principal, and longstanding, source of weakness, that is, the unwillingness of British banks to offer long-term finance (Froud et al, 2011; Hay, 2013; Watson and Hay, 1998; Williams et al, 1983). Finance sector reform is of course an issue relevant to rebalancing in its own right; the coalition government has instituted a new macro-prudential framework for bank regulation (augmenting the micro-prudential framework established by Labour), legislated for a 'ring fence' around individual deposits to shield them from risks associated with investment banking, and introduced a levy targeted at discourage excessive short-term borrowing. The government will claim that its regulatory changes in this area have been substantial, yet the agenda is clearly focussed on mitigating banking sector volatility and its effects, rather than reorienting bank lending and investment practices; the government's conservative approach is exemplified by the ongoing privatisation, largely unaltered, of the Royal Bank of Scotland and Lloyds Banking Group, forgoing an opportunity to lever reform of bank practices through strategic public ownership. The government has established the Green Investment Bank (GIB), ostensibly to direct investments to activities not well served by private banks, yet the GIB is limited in size and, in fact, not a bank in any meaningful sense (it cannot borrow money or issue credit). They have also rejected calls to establish a state investment bank, with a remit to invest more in Northern regions, 
and consistently opposed co-ordinated attempts by other European Union members to establish a tax on certain short-term financial transactions. There have been few genuine attempts to boost saving by individuals, although the coalition have taken forward the previous government's plans for automatic enrolment in private pension schemes. In general, extremely low interest rates drown out any initiatives designed to boost regular saving. Similarly, there has been virtually no action to curtail household indebtedness, despite some new restrictions on costly 'payday lending'.

Economic policies that have been pursued independently of the ostensible rebalancing agenda are also worth noting here. It is difficult to interpret quantitative easing (QE), for instance, in terms of rebalancing. Yet it is a crucial aspect of the coalition's economic stewardship. It has undoubtedly acted against the balance promoted in the government's communicative discourse by boosting the financial services sector, among other things, but whether such effects are intentional is arguable. Support for the housing market is also relevant; crucially, while the housing market has been identified as a key feature of the Anglo-liberal growth model, issues around housing have not featured heavily in rebalancing discourse. The coalition would probably argue that attempts to boost the housing market - indirectly through low interest rates, perhaps inadvertently through Funding for Lending, both noted above, and directly and deliberately through the mortgage guarantee scheme Help to Buy - are incidental to broader efforts to boost business investment, manufacturing, exports, and so forth. It is implausible, however, to suggest that the government is unaware of the role of a strong housing market in facilitating household consumption and, indeed, its less direct role in incentivising banks to lend to individuals rather than industry (a 'crowding out' effect).

We should of course not be surprised that the communicative discourse around rebalancing is an imperfect fit for the policy agenda being pursued in practice by the coalition government. It offers a simple idea that cannot possibly convey the motives behind countless, complex policy choices. At the same time, however, it offers a relatively novel means of describing an economic policy agenda that is in fact far from novel, or only novel in the sense that it intensifies practices long evident in British economic statecraft (or adopts new forms of intervention in order to preserve or restore aspects of the British economic model undermined by the financial crisis). In 
this context, it seems especially important that George Osborne revisited rebalancing discourse in 2014; whatever judgement we may form about its practical implications, rebalancing is certainly something the Conservatives and/or the coalition want to be able to claim has occurred, and still want to be seen to be pursuing.

\section{Evaluating the rebalancing act}

This section offers an empirical assessment of rebalancing, that is, progress towards redressing the imbalances highlighted in rebalancing discourse, between the eve of the financial crisis and the present moment (that is, the latest available data at the time of writing). The measures or 'benchmarks' included in this assessment are: the relative size of manufacturing and (financial) services in the British economy, and jobs and pay in these sectors; the extent to which bank lending practices have been reoriented, primarily towards manufacturing and away from the housing market; the relative size of different regions in the British economy, and employment and pay across the regions; median earnings and the earnings distribution; the relative importance of household consumption and (business) investment within GDP; the trade balance, and the extent to which the export base has been reoriented towards manufactured goods and emerging economies; the ratio of house prices to earnings, the level of mortgage approvals, and the extent of housing equity withdrawal; the extent of consumer borrowing, and the ratio of debt to disposable income, and; the savings ratio. Table 1 summarises the progress, or otherwise, explored in more detail below.

\section{Table 1: Summary of 'rebalancing' progress}

\begin{tabular}{lll}
\hline Issue & $\begin{array}{l}\text { Latest } \\
\text { data }\end{array}$ & \\
$\begin{array}{l}\text { Sectors } \\
\text { GVA }\end{array}$ & $\begin{array}{l}\text { Late } \\
2013\end{array}$ & $\begin{array}{l}\text { Slight fall for manufacturing, matched by finance/insurance, } \\
\text { although services sector in general grown to almost four-fifths } \\
\text { of the UK's GVA }\end{array}$ \\
Jobs & $\begin{array}{l}\text { Late } \\
2013\end{array}$ & $\begin{array}{l}\text { Large reduction in manufacturing jobs, contrasted with a small } \\
\text { reduction for finance/insurance and significant increase for } \\
\text { services in general }\end{array}$ \\
Pay & 2013 & $\begin{array}{l}\text { Both manufacturing and finance/insurance have seen rises in } \\
\text { pay relative to the national average, although pay in }\end{array}$
\end{tabular}




$\begin{array}{lll}\begin{array}{l}\text { Receipt of bank } \\ \text { lending }\end{array} & \begin{array}{l}\text { Early } \\ 2014\end{array} & \begin{array}{l}\text { Focus of bank lending on housing market has intensified, } \\ \text { although there has been a small reduction of proportion } \\ \text { devoted to financial intermediation. Proportion for } \\ \text { manufacturing almost halved to around 1 per cent }\end{array}\end{array}$

$\begin{array}{lcl}\text { Regions } \\ \begin{array}{l}\text { Contribution to } \\ \text { GVA }\end{array} & 2012 & \begin{array}{l}\text { Slight rise for London, with proportion for all other regions } \\ \text { declining }\end{array} \\ \text { GVA per head } & 2012 & \begin{array}{l}\text { Small rises for London and the South-East relative to national } \\ \text { measure. Slight rises for the North-West and North-East, } \\ \text { although all Northern regions remain substantially below } \\ \text { national measure }\end{array}\end{array}$

Unemployment Late Unemployment has risen in London and the South-East far less 2013 than all other regions; unemployment in Northern regions now higher than London

Pay Late Regional pay inequality largely unchanged, although small 2013 reduction in London's lead relative to national average, and significant reduction in relative pay in the North-East

\begin{tabular}{|c|c|}
\hline Trade & \\
\hline Trade balance & 2013 \\
\hline $\begin{array}{l}\text { Sectoral } \\
\text { composition of } \\
\text { exports }\end{array}$ & 2013 \\
\hline $\begin{array}{l}\text { Destination of } \\
\text { exports }\end{array}$ & 2013 \\
\hline
\end{tabular}

Small improvement in trade deficit, with exports increasing slightly faster than imports

Manufactured goods comprise lower proportion of the export base, with proportion for financial and business services largely unchanged

Dependence on Europe and the United States has reduced to some extent, although the BRIC countries account for only a slightly higher proportion of UK exports
Investment and consumption
Proportion of GDP Late Proportion of GDP accounted for by consumption unchanged; 2013 significant reduction for investment, including small reduction for business investment

$\begin{array}{lll}\text { Housing market } & & \\ \text { Size of market } & \text { Early } & \text { Significant reduction in the total value of mortgage approvals } \\ \text { House prices } & \begin{array}{l}\text { Early } \\ 2014\end{array} & \begin{array}{l}\text { Average prices now surpassed pre-crisis peak, although large } \\ \text { regional differences with London and the South-East } \\ \text { significantly above peak, and Northern regions still } \\ \text { significantly below }\end{array}\end{array}$

House $2013 \quad$ Slight fall in ratio of average price to median earnings, and price/earnings lower quartile price to lower quartile earnings ratio

Housing equity Late Fewer transactions and more housebuilding means equity is withdrawal $2013 \quad$ now being created rather than withdrawn 


\begin{tabular}{lll}
$\begin{array}{l}\text { Savings ratio } \\
\begin{array}{l}\text { Household debt- } \\
\text { to-income ratio }\end{array}\end{array}$ & $\begin{array}{l}\text { Early } \\
2014\end{array}$ & $\begin{array}{l}\text { Small rise in savings ratio compared to 2007, but with ratio } \\
\text { declining significantly as the economy returns to growth } \\
\text { Significant fall in debt-to-income ratio, but forecast to return to } \\
\text { pre-crisis levels over the next few years }\end{array}$ \\
$\begin{array}{l}\text { Earnings } \\
\text { Median earnings }\end{array}$ & 2013 & $\begin{array}{l}\text { Significant reduction in full-time earnings, exacerbated by shift } \\
\text { to lower-paid part-time employment and self-employment }\end{array}$ \\
$\begin{array}{l}\text { Earnings } \\
\text { distribution }\end{array}$ & 2013 & $\begin{array}{l}\text { Largely unchanged, although higher earners now earn slightly } \\
\text { more as proportion of national average, and lower earners } \\
\text { earn slightly less }\end{array}$ \\
\hline
\end{tabular}

There are, however, several analytical issues that must be explored initially. Firstly, an assessment of public-to-private sector rebalancing is beyond the scope of this article, since, as explored above, reducing the size of the public sector is seen to arise from the imperative of austerity rather than rebalancing in coalition discourse. Additionally, the public/private sector boundary is far from straightforward, and indeed can be directly manipulated by government. By contrast, and secondly, evidence on both the housing market and earnings is included, despite the fact that neither appears to have been identified as a rebalancing priority. Given the role the housing market has played in supporting household consumption in recent years (Watson 2010; Hay 2013), we consider evidence on its performance paramount to assessing the extent of economic change. Moreover, both this role for the housing market and the apparent decline or stagnation in earnings for many individuals are highlighted in ALGM analysis as key parts of the (flawed) pre-crisis economic model in the UK.

A third issue relates to the limitations of official data sources. There are of course inherent problems of time lag and definition: by the time evidence about a given trend is collected or codified, the trend may have changed (this problem is of course compounded by the time lag in the creation and publication of any assessment based on this evidence). More importantly, it must be recognised that official data are subject to the institutional dynamics and ideational pressures acting upon its creators, and may in some cases represent a strategic act by the creators in pursuance of a particular goal. Such problems are largely inescapable; the breadth of measures employed here mitigates, to some extent, against the imperfections inherent in each individual 
measure, but generally speaking, this means than any empirical analysis based on official data must be presented, and interpreted, cautiously.

Finally, there is the question of whether it is fair to evaluate the government's success in rebalancing the economy at this stage (that is, summer 2014). Problematically, while some of the evidence included here is relatively current, at the time of writing, in some cases the latest available evidence is much earlier than 2014 (2012, for instance, in the case of regional output data). Typically, however, the evidence presented here relates the pre-crisis period to the end of 2013 or early 2014. It is of course correct to say that rebalancing may occur in the future, or may be happening presently, as a result of changes enacted by the coalition government, even if not yet evident (evidence from official forecasts is also presented below, where available, to partially alleviate this problem - although forecasts clearly compound many of the problems related to the production of official statistics). However, even if all the data were current, and forecasts were wholly reliable, it may still be the case that the success of rebalancing, or otherwise, cannot be judged over such a short period of time. A number of responses to this charge are possible. Firstly, evaluating progress now does not preclude subsequent evaluation, and may indeed be useful to policy-makers insofar as they are able to chart progress to date. Secondly, whether credible in its own terms or not, rebalancing has been presented as a coalition government priority - and the coalition was not designed to last beyond 2015. Having said this, and thirdly, it is necessary to reiterate that the analysis here is not designed simply to evaluate the economic policy performance of the coalition government. The first section noted that rebalancing is not exclusively a coalition agenda, and the second section noted that the coalition's economic policy programme has not focused on rebalancing to any meaningful extent. Moreover, the analysis includes issues which have not featured significantly in coalition discourse on rebalancing. It is best conceived as an evaluation of post-crisis change within the British economy - albeit an agenda for change which the coalition government is, in large part, publicly committed. Fourthly, to agree with the proposition that rebalancing cannot have been expected to have occurred by 2014 (or earlier) is to accept uncritically the notion that there is such a thing as economic balance, that can be met at some future point (just not yet). This article challenges this premise. 
There is little evidence of a rebalancing between the manufacturing and services sectors in the British economy. In the third quarter of 2007, manufacturing represented around 11 per cent of Britain's gross value added (GVA); by the third quarter of 2013, it had fallen to 10 per cent. Finance and insurance had also fallen over this period, from 10 per cent to 9 per cent, although the proportion of Britain's GVA represented by the services sector in general rose from 77 per cent to 79 per cent. In terms of jobs, the manufacturing sector lost around 330,000 jobs over this period (a 12 per cent reduction), whereas finance and insurance saw a reduction of around 30,000 jobs (2 per cent), and the services sector in general saw an increase of 1.3 million jobs ( 5 per cent). Pay levels also offer little sign of rebalancing. In 2007 average weekly pay in manufacturing was 13 per cent above the national average - this rose to 17 per cent in 2013. Finance and insurance workers, however, were paid 116 per cent more than the national average in 2007, rising to 119 per cent by 2013. In the services sector in general, workers were paid 97 per cent of the national average in both 2007 and $2013 .{ }^{2}$

In terms of the availability of credit, the concentration of bank lending on the housing market, at the expense of manufacturers, has intensified. In the fourth quarter of 2007, 35 per cent of lending by British monetary financial institutions to British residents went to individuals, including 28 per cent to lending secured on dwellings (that is, mortgages). Financial intermediation (and auxiliary activities) accounted for 36 per cent of lending, and manufacturing accounted for only 2 per cent. In the first quarter of 2014, 48 per cent of lending went to individuals, including 44 per cent to lending secured on dwellings. Financial intermediation accounted for 28 per cent of lending, and manufacturing accounted for an even lower proportion, just over 1 per cent. $^{3}$

\section{Regions}

Similarly, there is little evidence of rebalancing between Britain's regions and nations. In 2007, London represented 21 per cent of Britain's GVA; by 2012 (the latest available data), this had risen to 22 per cent. Every other region, and the devolved nations, shrank in relative terms over this period (with the exception of the South East, where the 
proportion was constant as 14 per cent). In terms of GVA per head across the regions, in London this measure increased from 168 per cent of the national average to 172 per cent between 2007 and 2012, and in the South East it increased from 105 per cent of the national average to 107 per cent. Most other regions, and the devolved nations, saw their relative score decline; there were slight increases in the North West and North East, although in 2012 these regions had a GVA per head, respectively, only 85.1 per cent and 74.3 per cent of the national average.

Interestingly, while at the end of 2007 London had a higher unemployment rate than anywhere else in Britain, by the end of 2013 its unemployment rate had fallen below that of the three regions of Northern England, and the West Midlands (similarly, its employment rate had risen above these regions). Unemployment has risen in all regions over this period, although far less in the South East and East of England - the regions with the lowest unemployment rates at the end of 2007 - than anywhere else, with the exception of London. Regional pay inequality has remained largely unchanged between the end of 2007 and the end of 2013. Measured in terms of gross weekly earnings among full-time employees, pay in London is slightly lower as a proportion of the national average, having fallen from 126 per cent to 124 per cent. Average pay in the three regions of Northern England, and Northern Ireland, remains below 90 per cent of the national average, and has fallen dramatically in the North East from 87 per cent to 82 per cent. 4

Trade

Britain's trade balance remains in deficit, but has improved. From 2011 to 2013, the average annual deficit was around $£ 29$ billion, whereas from 2005 to 2007 it was almost $£ 36$ billion (it is useful to consider trade data over a longer period than a single year, because year-on-year fluctuations tend to be significant). The value of total imports has increased over this period, but the value of exports has increased at a slightly faster rate. However, when the sectoral composition of the export base is considered in more detail, the rebalancing story seems somewhat less convincing. Financial services made up the same proportion of total exports in 2011-2013 that they did in 2005-2007, 10 per cent, and business services exports make up a higher 
proportion, rising from 10 per cent to 11 per cent. The export base is also now more dependent on oil, with the proportion rising from 6 per cent to 8 per cent over this period. The proportion of exports accounted for by both finished manufactured goods and semi-manufactured goods has fallen from, respectively, 32 per cent to 29 per cent, and 19 per cent to 17 per cent.

In terms of export destinations, Britain's dependence on trade with Europe has lessened only slightly. In fact, Germany has overtaken the United States as Britain's most important export destination - although at the same time, the trade balance with Germany has deteriorated slightly from a deficit of $£ 20$ billion in 2007 to $£ 23$ billion in 2013. The proportion of total exports going to the Netherlands, France and Ireland - the UK's other key trading partners in 2007 - has also increased significantly; the significant trade deficit previously evident with both the Netherlands and France has receded slightly. There is some sign of the export base being reoriented to emerging economies. Between 2007 and 2013, the proportion of exports going to China, India and Brazil increased, but only from, respectively, 1 per cent to 2.5 per cent, 0.8 per cent to 1 per cent, and 0.3 per cent to 0.5 per cent. More importantly, trade deficits with both China and India increased significantly, although a tiny trade deficit with Brazil has been converted into an even tinier trade surplus. ${ }^{5}$ Chart 1 shows change over time in the proportion of UK exports accounted for by the European Union, North America, the BRIC countries, and the rest of the world. 


\section{Chart 1: Proportion of UK exports to selected countries/regions}

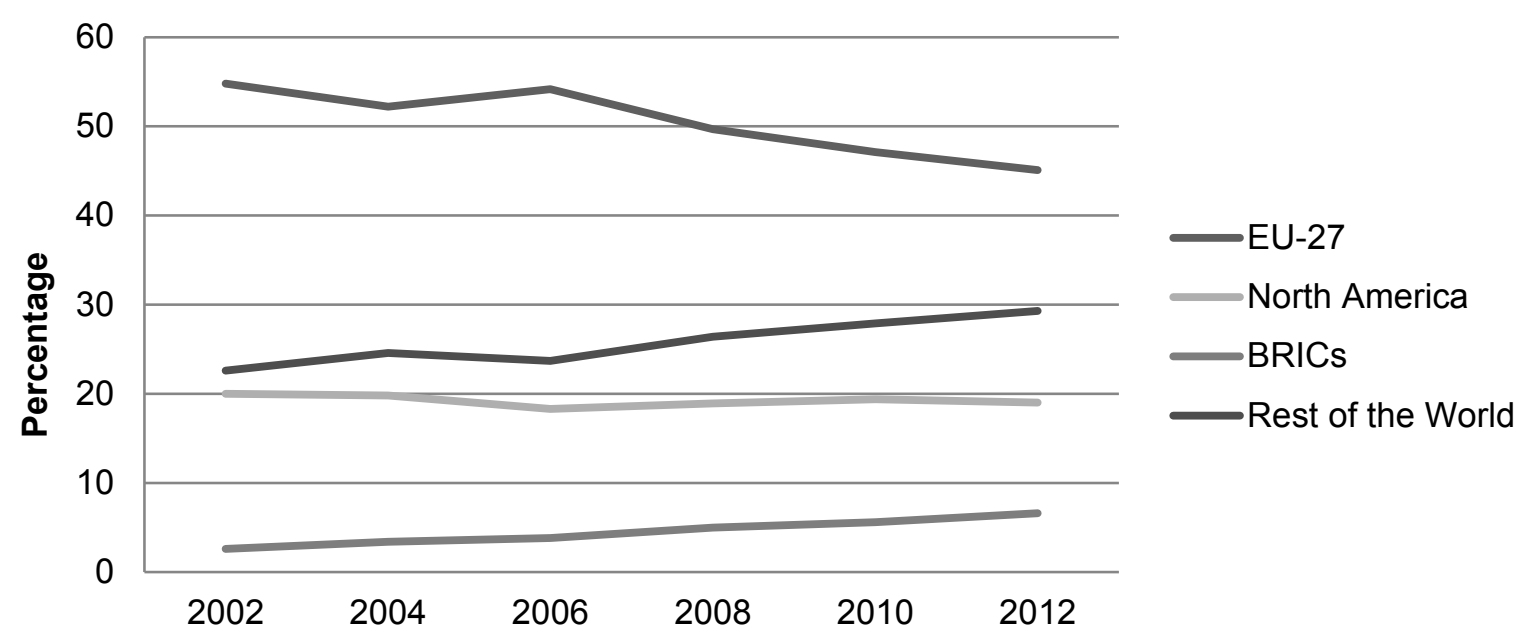

Source: ONS (2013)

Investment and consumption

Although neither substitutes for the other, increasing the proportion of gross domestic product (GDP) accounted for by investment (particularly business investment), at the expense of consumption, is a key rebalancing objective. However, there has been no progress in this regard. In the fourth quarter of 2013, the proportion of the British economy's output accounted for by household final consumption expenditure was 62 per cent, a slight increase on the figure for the fourth quarter of 2007, 61.7 per cent. The proportion accounted for by investment (that is, gross fixed capital formation, declined significantly over this period, from 17.8 per cent to 14.5 per cent, including a slight fall in the proportion accounted for by business investment, from 8.7 per cent to 8.2 per cent. 6

Official economic forecasts, however, predict a strong recovery in investment in coming years. Despite the presumption of a 1 per cent decline in business investment throughout 2013, the Office for Budget Responsibility (OBR) expects annual business investment growth to average 8 per cent from 2014 to 2017. However, business investment is the component of GDP that has, since the recession, been forecast incorrectly most consistently. From 2011 to 2013, annual business investment growth 
has averaged 2 per cent. In 2010, the OBR expected this figure to be 9 per cent, and in 2011 they expected it to be 5 per cent. In 2012, the OBR expected business investment growth in 2013 to be 5 per cent, compared to an outturn of -1 per cent. The OBR explains, in its 2014 forecast, that business investment is linked to overall economic growth - because the growth they expected previously did not materialise, nor did the business investment (see OBR, 2010; 2011; 2012; 2013; 2014). However, no evidence for this view is presented; this does not necessarily make it an unreasonable assumption, although no such association was evident during the immediate pre-crisis period, when strong overall GDP growth did not coincide with strong business investment growth.

\section{Housing market}

The housing market has not recovered all of the ground lost as a result of the financial crisis and recession. The value of total mortgage approvals in January 2014 was $£ 19$ billion, compared to $£ 34$ billion in January $2007 . .^{7}$ Yet the average price of the houses that are being traded has now exceeded its pre-crisis peak, with the average house price in the UK in the second quarter of 20141.3 per cent above the average for the third quarter of 2007. This trend, however, hides a quite remarkable regional divergence. According to the widely-used Nationwide House Price Index, average house prices in the North-West (excluding Cumbria) have fallen by 8.9 per cent over this period, and by 8.8 and 7 per cent, respectively, in Yorkshire and Humberside, and the North-East and Cumbria. In contrast, the average house price in London rose by 32.4 per cent over this period, and by 14.3 per cent in the outer metropolitan area of London, and 7 per cent in the rest of the South-East. ${ }^{8}$ Prices are of course now rising steadily in all of the Northern regions, albeit not as quickly as in London and the South-East. In terms of house prices relative to earnings, the ratio of median house price to median annual earnings (of fulltime employees) in England fell slightly from 7.2 in 2007 to 6.7 in 2013. However, it remains much higher than the ratio evident in the late 1990s and early 2000s. There is a similar story at the lower end of the housing market: the ratio of the lower quartile house price to lower quartile median earnings in England fell slightly from 7.2 to 6.5, although this much higher than the ratio evident in the late 1990s and early 2000 s. $^{9}$ 
The prevalence of housing equity withdrawal (the difference between net secured lending to households, and increases in the stock of housing wealth when either new properties are built, or improvements are made to existing ones) was an important feature of the pre-crisis growth model, and helped to fund consumption despite the 'squeeze' on earnings (Hay, 2013). From late 2006 to late 2007, an average of almost $£ 9$ billion in housing equity per quarter was withdrawn per quarter. However, housing equity is no longer being withdrawn on this scale, and indeed withdrawals are now negative, with an average of almost $-£ 12$ billion per quarter being withdrawn from late 2012 to late 2013.10 The Bank of England, however, has suggested that this reversal does not in fact represent a fundamental economic change, but rather reflects the fact that fewer housing transactions are restricting the opportunity for equity withdrawals (Reinold, 2011), and that a higher rate of housebuilding (associated with Help to Buy) has led to the creation of new equity (Stewart, 2013).

\section{Debt and savings}

The savings ratio (household saving as a proportion of total household resources) appears initially to have been the most successful example of rebalancing since 2010 . The ratio has increased from 3 per cent in the third quarter of 2007, to 5 per cent in the first quarter of 2014. To put this into context, the savings ratio was only 3.9 per cent in the third quarter of 2001. However, this simple account ignores the relationship between the phase of the business cycle and saving. The saving ratio actually climbed dramatically before the coalition government took office, to around 8 per cent throughout 2009 and early 2010, and the most recent figure is a 'snapshot' in a saving ratio that has since declined significantly. Indeed, the OBR (2014) forecasts that the savings ratio will fall back further, declining to 3.6 per cent as early as 2016 . During the last recession, in the early 1990s, the savings ratio peaked at a higher rate, around 11 per cent, and did decline significantly for several years afterwards. It is reasonable to conclude, therefore, that the economy has not witnessed an unusually large swing towards savings. ${ }^{11}$

Similarly, there is some evidence that households are reducing indebtedness - yet this may prove to be illusory. The household debt-to-income ratio (total financial liabilities 
as a proportion of gross disposable income) has fallen to 141 in 2013, from a height of 169 in 2007.12 The OBR (2014), however, forecasts that, rather than continuing to decline, the ratio will actually return (almost) to its pre-crisis level by 2019. The amount owed in consumer debt has fallen to $£ 161$ billion in January 2014 from $£ 191$ billion in January 2007, but this is still much higher than the $£ 116$ billion owed in January 2000. Furthermore, a greater proportion of consumer debt is now held on credit cards, 36 per cent in January 2014 compared to 29 per cent in January 2007.13

\section{Earnings}

Evidence on changes in relative pay across sectors and regions was presented above. It is also worth considering earnings in general, however, given the political interest in this area, and the identification of stagnating earnings by ALGM analysis as a key precipitator of the economic downturn. Between 2008 (the pre-crisis peak, according the Annual Survey of Hours and Earnings) and 2013, median earnings fell by 7.7 per cent in real terms for full-time employees. This represents an intensification of pre-crisis trends: from 2004 to 2008, median earnings rose by only 3. 9 per cent, compared to 10.9 per cent from 2000 to 2004 . It is of course worth reiterating that this data relates to full-time employees; the UK has seen a rise in both part-time work and selfemployment since 2008. Part-time employees typically earn less per hour than those working full-time, and while individuals in self-employment typically earned more than employees in the years immediately before the crisis, they now earn significantly less on average (Murphy, 2013). In terms of the earnings distribution, earnings at the $75^{\text {th }}$ percentile rose slightly from 153.1 per cent of median earnings in 2007, to 154.5 per cent in 2013. Earnings at the $90^{\text {th }}$ percentile rose from 217.1 per cent to 218.5 per cent over this period. Lower earnings (whether in terms of the $10^{\text {th }}$ or $25^{\text {th }}$ percentile) have fallen slightly further behind the median - reversing the slight 'catch up' that was evident in the decade up to $2007 .{ }^{14}$

The failure of rebalancing?

Although our analysis is inevitably partial, it is appropriate to conclude that, on the basis of the available evidence, there is little sign of rebalancing within the British 
economy, on the terms publicly espoused primarily by the coalition government. Should we therefore conclude that rebalancing has failed? It is worth reiterating the caveats that such rebalancing may yet occur, and that our analysis covers issues not included substantively in coalition discourse. It should also be noted that the absence of (progress towards) balance may be due to circumstances over which the government has no meaningful control. This argument implies the existence of external constraints on what national-level governments may achieve, even in relation to the domestic economy. It clearly has some merit; arguing that rebalancing has not occurred is not the same as arguing that it could easily have been achieved if the government had been more committed to the agenda. On the other hand, the coalition government have undoubtedly claimed that rebalancing is possible.

The underlying issue here, of course, is whether we should expect policy-makers' communicative discourse to match 'reality' to any meaningful extent. It would be naïve to claim that the mismatch presented here is anything other than normal political fare; indeed, there is little basis for claiming that the mismatch related to rebalancing were any more pronounced than we would usually expect. However, despite this, it is relevant that the main thrust of coalition economic policy appears to have been relatively unconcerned with bringing about rebalancing, or at least highly disconnected from the publicly espoused agenda. Furthermore, it is also relevant that the government now appears to be claiming that rebalancing is happening. This rhetorical shift is achieved by removing some priorities from the presentation of the rebalancing agenda, such as reducing private debt, or by adopting far less stringent measures than those used here (such as evidence of any growth in manufacturing or Northern regions, irrespective of its relative strength) (see Osborne, 2014a; 2014b). This highlights the central ambiguity inherent in rebalancing discourse: it is a discourse that was always bound to offer some scope for claiming success, insofar as mundane economic circumstances can be described as evidence of rebalancing. The ostensible failure of rebalancing to date indicates that the main purpose of the discourse is not to win support for an ambitious policy programme, but rather to offer the appearance that radical change is being pursued, therefore offering accommodation to moderate critics such as Vince Cable by demonstrating a shared agenda, while at the same time legitimating the basic features of the existing economic order. The question of whether 
rebalancing has failed is trumped therefore by the sense that rebalancing is both eminently achievable, in that it can be moulded to suit particular circumstances, but also quintessentially unachievable, in that it rests upon a simplistic vision of the British economy which appears to have been proven, in practice, impermeable to the highly circumscribed forms of state intervention countenanced by the rebalancing imperative.

It is in this context that we refer to what might be termed the 'communicative dissonance' of rebalancing discourse - a consistent disjuncture between, on the one hand, the avowed central objective of government policy (at least as communicated publicly) and, on the other, the broad contours of substantive government economic policy making as gauged by a detailed analysis of policy content and implementation. Though communicative dissonance is, of course, to be expected in all areas of public policy-making and from one administration to another (communicative discourse rarely corresponds in any one-to-one fashion with policy content), it is, we would contend, a particularly distinctive feature of the coalition's economic agenda. At a time of acknowledged economic crisis, that is perhaps both a surprising and a significant observation. We see little if any evidence that rebalancing has actively been attempted (even assessed in the coalition's own terms) and yet plenty of evidence that rebalancing has been the defining public mantra of its period of economic policy tenure. As such, we suggest, rebalancing cannot be judged a failure; for there is as yet no rebalancing agenda to fail.

\section{Conclusion}

Assessing the extent to which the British economy has rebalanced offers a useful insight into the extent of economic change following the financial crisis. Though the evaluation offered in this article cannot be considered comprehensive, and indeed covers issues that have not been an explicit part of the coalition government's public espoused rebalancing imperative, it does help us to provide perhaps the first assessment of the coalition's economic policy on its own terms. Of course, it is precisely because the assessment is framed by the coalition's own rhetoric on economic change that we might expect some progress to have been made towards economic balance. That this appears 
not to be the case, with even the limited signs of progress in some areas likely to prove illusory, is surely telling.

We could conclude that this apparent (if, as we have argued, somewhat misleading) 'failure' is due to the inability of national-level governments to achieve substantial economic change, especially over a short timeframe, or because rebalancing has not been pursued in practice by policy-makers, despite their public pronouncements. However, whilst neither conclusion is wrong, each in our view misreads and misinterprets the purpose of rebalancing discourse, that is, to communicate the coalition government's plans and expectations around the economy in a particular way, for public consumption. On the assessment offered here, rebalancing is not being achieved, but the imagery of balance and the rebalancing imperative and the implicit moral political economy on which it rests allows the coalition to escape responsibility for any failure on its part to achieve the rebalancing it ostensibly seeks, whilst continuing to apportion blame to others for the imbalance it is forced to seek to redress. Progress towards rebalancing is good (if slow); lack of progress is merely an index of the extent of the mess it inherited from its predecessor. More generally, the absence of any substantive progress to date has not deterred the coalition government from continuing to claim that rebalancing is both desirable and possible - seemingly because it offers a narrative which appears to endorse radical change, while at the same time legitimating the current economic order.

\section{Notes}

1. The Pension Infrastructure Platform was announced by the government in 2011, and is managed by the National Association of Pension Funds (NAPF). In contrast to an initial target of $£ 20$ billion, it has attracted only around $£ 1$ billion in 'soft' commitments, with only $£ 260$ million of this committed at the time of writing. Of the ten funds offering soft commitments, three are conglomerates of local government pension funds, and four are funds related to previously nationalised industries. They are joined by the Lloyds TSB Group Pension Schemes - of which the sponsoring company is publicly owned in large part - and the Pension Protection Fund, a government-sponsored body which administers the pensions of members of insolvent funds (Mann, 2013; NAPF, 2014). 
2. Data on output, jobs and pay by industry/sector is available on the Office for National Statistics (ONS) website, available at www.ons.gov.uk. Pay data is from the Monthly Wages and Salaries Survey; this was chosen ahead of the Labour Force Survey as results from the former are published at a lower level of disaggregation, although the latter consistently reports manufacturing pay below the national average.

3. Data on bank lending is available on the Bank of England's Bankstats website, available at www.bankofengland.co.uk/statistics/Pages/bankstats/default.aspx.

4. Data on output, employment and pay by region is available on the ONS website. Pay data is from the Labour Force Survey.

5. Data on trade is available on the ONS website.

6. Data on output is available on the ONS website.

7. Data on mortgage approvals is available on the Bank of England's Bankstats website.

8. Data from the Nationwide House Price Index is available at http://www.nationwide.co.uk/about/house-price-index/download-data

9. These statistics are derived from Land Registry data in combination with earnings data, and published by the Department for Communities and Local Government on the British government's website, available at https://www.gov.uk/government/organisations/department-for-communitiesand-local-government/about/statistics.

10. Data on housing equity withdrawal is available on the Bank of England's Bankstats website.

11. Savings ratio statistics are available on the ONS website.

12. These statistics are derived from data on financial liabilities and disposable income available on the ONS website. In order to enable comparison with 2007, 2013 liabilities refer to the end of the third quarter, and 2013 disposable income is an annualised amount based on data for the first three quarters.

13. Data on consumer borrowing is available on the Bank of England's Bankstats website.

14. Data from the Annual Survey of Hours and Earnings on median earnings, full-time and part-time earnings, and the earnings distribution is available from the ONS website. It should be noted that slight changes in the survey's methodology in 2004, 
2006 and 2011 mean that annual results have been compared cautiously, although the changes appear to have led to only minor modifications.

\section{References}

Adorno, T. W. (1973) Negative Dialectics (London: New Left Books).

Antonio, R. J. (1981) 'Immanent critique as the core of critical theory', British Journal of Sociology, 32 (3), 330-345.

Brewer, M., Browne, J. and Jin, W. (2011) 'Universal Credit: a preliminary analysis', Institute for Fiscal Studies Briefing Note 116. Available at: http://www.ifs.org.uk/publications/5415

Brown, G. (2010) Beyond the Crash: Overcoming the First Crisis of Globalisation (London: Simon and Schuster).

Buigues, P.-A. and Sekkat, K. (2009) Industrial Policy in Europe, Japan and the United States: Amounts, Mechanisms and Effectiveness (Basingstoke: Palgrave Macmillan). Cable, V. (2013) 'Speech to the Industrial Strategy Conference 2013', speech delivered on 11 September 2013. Available at: https://www.gov.uk/government/speeches/industrial-strategy-conference-2013

Cameron, D. (2010) 'Transforming the British economy: coalition strategy for economic growth', speech delivered on 28 May 2010. Available at:

https://www.gov.uk/government/speeches/transforming-the-british-economycoalition-strategy-for-economic-growth

Clift, B. and Tomlinson, J. (2006) 'Credible Keynesianism? New Labour macroeconomic policy and the political economy of coarse tuning', British Journal of Political Science, $37: 1,47-69$

Conservative Party (2010) An Invitation to Join the Government of Britain: The Conservative Manifesto 2010. Available at: http://media.conservatives.s3.amazonaws.com/manifesto/cpmanifesto2010_lowres. pdf

Crouch, C. (2009) 'Privatised Keynesianism: an unacknowledged policy regime', British Journal of Politics and International Relations, 11:3, 382-399.

Crouch, C. (2011) The Strange Non-Death of Neoliberalism (Cambridge: Polity). 
Darling, A. (2009a) 'Budget speech', speech delivered on 22 April 2009. Available at: http://www.theguardian.com/uk/2009/apr/22/budget-2009-alistair-darlingspeech

Darling, A. (2009b) 'Pre-Budget Report speech', speech delivered on 9 December 2009. Available at https://www.labour.org.uk/pre-budget-report-2009 (accessed 28 March 2014)

Financial Times (2005) 'A new economic landscape revealed', Financial Times, 2 July. Available at: http://www.ft.com/cms/s/0/f8a41930-ea94-11d9-aa7a00000e2511c8.html?siteedition=uk\#axzz2xp0HsJFp

Froud, J., Sukhdev, J., Law, J., Leaver, A. and Williams, K. (2011) 'Rebalancing the economy (or buyer's remorse)', CRESC Working Paper No.87. Available at: http://www.cresc.ac.uk/publications/rebalancing-the-economy-or-buyers-remorse

Hay, C. (2004) 'Credibility, competitiveness and the business cycle in 'Third Way' political economy: a critical evaluation of economic policy in Britain since 1997', New Political Economy, 9(1), 39-56.

Hay, C. (2013) The Failure of Anglo-Liberal Capitalism (Basingstoke: Palgrave).

Hay, C. and Payne, A. (2015) Civic Capitalism (Cambridge: Polity).

Hay, C. and Rosamond, B. (2002) 'Globalization, European integration and the discursive construction of economic imperatives', Journal of European Public Policy, 9(2), 147167.

Hay, C. and Smith, N. (2005) 'Horses for courses? The political discourse of globalisation and European integration in the UK and Ireland', West European Politics, 28(1), 124158.

Helm, D. (2013) 'Britain in knots over infrastructure', Financial Times, 1 February. Available at: http://www.ft.com/cms/s/0/ff450d84-6bbb-11e2-a70000144feab49a.html?siteedition=uk\#axzz2bK3MRBYd

Hindmoor, A. and McConnell, A. (2013) ‘Why didn't they see it coming? Warning signs, acceptable risks and the global financial crisis', Political Studies, 61:3, 543-560.

HM Government (2010) The Coalition: Our Programme for Government. Available at: https://www.gov.uk/government/uploads/system/uploads/attachment_data/file/7 8977 /coalition_programme_for_government.pdf

HM Treasury (2009) Securing the Recovery: Growth and Opportunity: Pre-Budget Report, December 2009. Available at: 
http://webarchive.nationalarchives.gov.uk/+/http:/www.hmtreasury.gov.uk/d/pbr09_completereport.pdf

HM Treasury and Department for Business, Innovation and Skills (2011) The Plan for Growth. Available at:

https://www.gov.uk/government/uploads/system/uploads/attachment_data/file/3 1584/2011budget_growth.pdf

House of Commons Treasury Committee (2008) Re-appointment of Mervyn King as Governor of the Bank of England: Volume II, Oral and Written Evidence. Available at: http://www.publications.parliament.uk/pa/cm200708/cmselect/cmtreasy/524/52 4ii.pdf

King, M. (2002) 'Rebalancing the United Kingdom's economy', speech at the British Chambers of Commerce National Conference, 23 April 2002. Available at http://www.bis.org/review/r020423c.pdf

Liberal Democrats (2010) Liberal Democrat Manifesto 2010. Available at: http://network.libdems.org.uk/manifesto2010/libdem_manifesto_2010.pdf

King, M. (2002) 'Rebalancing the United Kingdom's economy', speech delivered on 23 April 2002. Available at http://www.bis.org/review/r020423c.pdf

Mandelson, Peter (2010) 'Going for growth: building Britain's future economy', speech delivered on 6 January 2010. Available at: http://www.theworkfoundation.com/assets/docs/peter\%20mandelson\%20speech. pdf

Mann, N. (2013) 'Ten pension funds signed up for infrastructure platform', The Actuary, 19 February. Available at: http://www.theactuary.com/news/2013/02/ten-pensionfunds-signed-up-to-infrastructure-platform/

Miliband, E. (2014) 'Speech on regional devolution', speech delivered on 8 April 2014. Available at: http://labourlist.org/2014/04/full-text-milibands-speech-on-regionaldevolution/

Murphy, R. (2013) Disappearing Fast: The Falling Income of the UK's Self-Employed People. Available at: www.taxresearch.org.uk/Documents/SEI2013.pdf National Association of Pension Funds (2014) ‘Pensions Infrastructure Platform announces PPP PIP equity fund'. Available at: http://www.napf.co.uk/PressCentre/Press_releases/0387-PIP-PPP-equity-fund.aspx 
Office for Budget Responsibility (2010) Economic and Fiscal Outlook: November 2010. Available at http://budgetresponsibility.org.uk/economic-and-fiscal-outlooknovember-2010/

Office for Budget Responsibility (2011) Economic and Fiscal Outlook: November 2011. Available at: http://budgetresponsibility.org.uk/economic-and-fiscal-outlooknovember-2011/

Office for Budget Responsibility (2012) Economic and Fiscal Outlook: December 2012. Available at: http://budgetresponsibility.org.uk/economic-and-fiscal-outlookdecember-2012/

Office for Budget Responsibility (2013) Economic and Fiscal Outlook: December 2013. Available at: http://budgetresponsibility.org.uk/economic-fiscal-outlook-december2013/

Office for Budget Responsibility (2014) Economic and Fiscal Outlook: March 2014. Available at: http://cdn.budgetresponsibility.org.uk/37839-OBR-Cm-8820accessible-web-v2.pdf

Office for National Statistics (2013) The Pink Book: 2013. Available at: http://www.ons.gov.uk/ons/rel/bop/united-kingdom-balance-ofpayments/2013/index.html

Osborne, G. (2010) 'Mais lecture: a new economic model', speech delivered on 24 February 2010. Available at: http://www.totalpolitics.com/print/speeches/35193/george-osborne-mais-lecturea-new-economic-model.thtml

Osborne, G. (2014a) 'Budget speech', speech delivered on 21 March 2014. Available at: http://www.theguardian.com/uk/2012/mar/21/budget-speech-2012-full-text

Osborne, G. (2014b) 'Economy speech in Hong Kong', speech delivered on 20 February 2014. Available at: https://www.gov.uk/government/speeches/chancellorseconomy-speech-in-hong-kong

Reinold, Kate (2011) 'Housing equity withdrawals since the financial crisis' in Bank of England Quarterly Bulletin: 2011 Q2. Available at: http://www.bankofengland.co.uk/publications/Documents/quarterlybulletin/qb11 0205.pdf

Schmidt, V. (2008) ' Discursive institutionalism: The explanatory power of ideas and discourse', Annual Review of Political Science, 11, 303-326. 
Stewart, H. (2013) 'Homeowners inject record $£ 15.4$ billion into housing market', The Guardian, 2 October. Available at:

http://www.theguardian.com/business/2013/oct/02/homeowners-inject-record15bn-equity-housing-market

Watson, M. and Hay, C. (1998) 'In the dedicated pursuit of dedicated capital: restoring an indigenous investment ethic to British capitalism', New Political Economy, 3:3, 407-426.

Watson, M. and Hay, C. (2004) 'The discourse of globalisation and the logic of no alternative: rendering the contingent necessary in the political economy of New Labour', Policy \& Politics, 31(3), 289-305.

Watson, M. (2010) 'House Price Keynesianism and the Contradictions of the Modern Investor Subject', Housing Studies, 25:3, 413-426.

Williams, K., Williams, J. and Thomas, D. (1983) Why Are the British Bad at Manufacturing?, (London: Routledge \& Kegan Paul).

Wintour, P. (2014) 'Ed Miliband: Labour will use English devolution to rebalance UK growth', The Guardian, 7 April. Available at:

http://www.theguardian.com/politics/2014/apr/07/ed-miliband-labour-cityregions-uk-growth 
Tables and charts

Chart 1: Proportion of UK exports to selected countries/regions

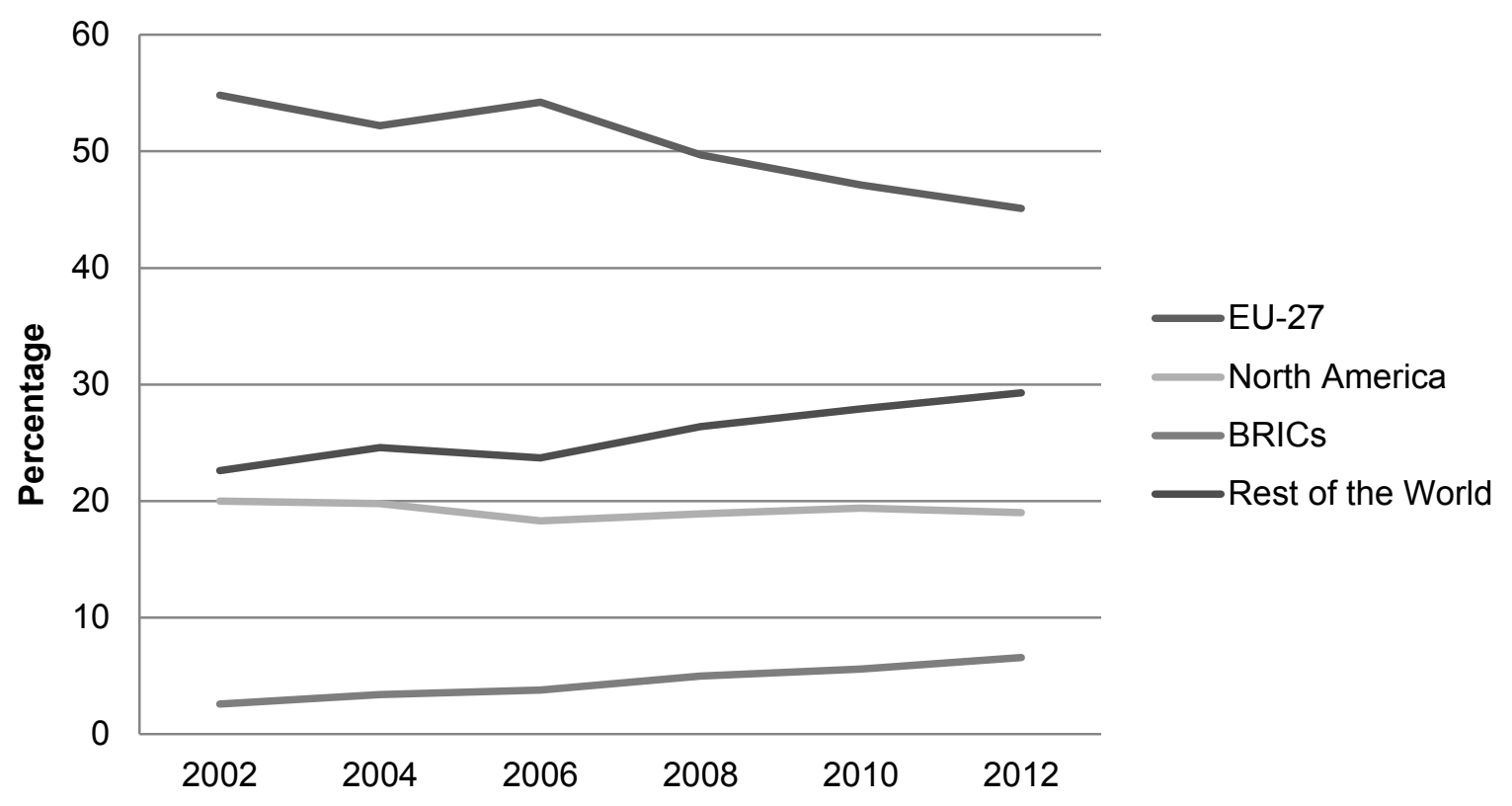

Source: ONS (2013) 